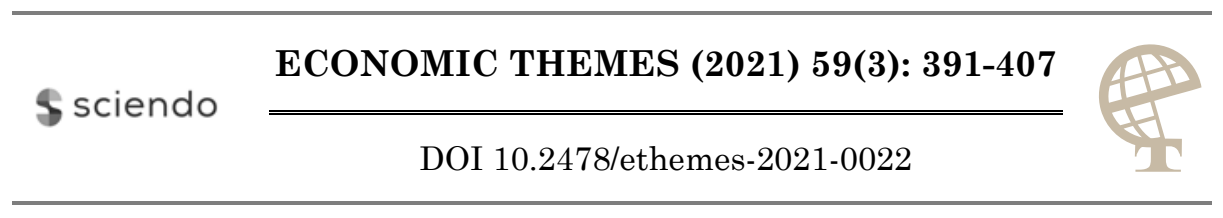

\title{
SUPPLIER SELECTION PROCESS BASED ON GREEN APPROACH
}

\author{
Aleksandra Anđelković \\ University of Niš, Faculty of Economics, Serbia \\ $\square$ aleksandra.andjelkovic@ekonomski.rs \\ Goran Milovanović \\ University of Niš, Faculty of Economics, Serbia \\ $\bowtie$ goran.milovanovic@ekonomski.rs
}

UDC

658.7:

5502.12

Review

paper

Received:

25.01.2021

Accepted:

02.07.2021
Abstract: The focus on profit and continuous struggle for increasing market share has gradually led to the neglect of the environment. The opportunist behavior of companies by threatening of ecological environment has led to a indirect neglect of its consumers. According to that, the implementation of green approach in all business areas has to be present. When it comes to a supply chain and its sustainability in an ecological sense, the question of adequate choice of suppliers and/or partners is a priority. The process of supplier selection is the first stage in the process of designing the supply chain. Therefore, this phase will decide whether the whole supply chain will be green-oriented. The aim of the paper is to point out the increasing implementation of the green approach in the supply chain, and above all in the supplier selection process. In addition, the paper analyses the impact of the economic environment as a factor of implementation of the green approach. In order to verify the hypothesis, the authors analyze EPI and LPI indexes, as well as the correlation between them. According to the results of the analysis, the authors indicate which countries are the green destinations and also the source of the green suppliers (green partners).

Keywords: green approach, supply chain, suppliers, environment, EPI, LPI

JEL classification: Q56, L14, O13 


\section{Introduction}

Global supply chains become a great source of competitive advantage, and for that reason they are very important for increasing the profitability of each supply chain partner (Islam et al., 2013). Through a supply chain, partners have a better opportunity to overcome problems, such as: the lack of resources, the lack of knowledge and experience, high production costs and inventory level, but also the supply chain could be the source of uncertainties and risks (Viswanadham \& Samvedi, 2013). Due to the nature of complexity of the supply chain, the network with a great number of partners, flows, and opposing goals, there is a need for continuous improvement of the supply chain process (Viswanadham \& Samvedi, 2013).

Supply chains are focused on cost reduction and higher efficiency of all processes with the purpose to deliver raw materials and goods at the right place and at the right time. For that reason, the supply chains look for appropriate strategies, such as lean production, just-in-time, just-in-sequence, sourcing from one or multiple sources, and outsourcing from low-cost countries or best-cost countries (Viswanadham \& Samvedi, 2013). However, through realizing those strategies and activities, global supply chains become one of the key environmental contaminants (Islam et al., 2013). In addition, companies, as partners in the supply chain, depend on achieving economic aims and often forget about social and environmental welfare or recognize them as secondary aims (Varsei et al., 2014).

Green supply chains are similar to traditional supply chains. The key difference is that beside economic aims, green supply chains are interested in environmental impact. The green supply chain presents the integration of environmental dimension into a business network (Tseng et al., 2019; Kim et al., 2016). Designing green supply chain is some kind of a trade-off between the supply chain profitability and economy development, on one side, and the environmental protection, on the other side (Frota Neto et al., 2008).

Partners' selection, according to supply chain requirements, is the first phase of the supply chain development. For that purpose, it could be used a lot of different criteria, such as cost, quality, lead time, timeliness, completeness etc. However, as a response to the market's requirement for the environmental protection, companies increasingly look for those criteria in the process of partner's selection (Banaeian et al., 2015). The decision making about the supplier selection, according to the environmental protection, is the basis of developing green supply chain (Hou \& Xie, 2019).

The aim of the paper is to highlight the importance and growing interest for the developing green supply chains, with a special emphasis on the implementation of the green approach in the supplier selection process. In addition, the authors of the paper, through analyzing LPI and EPI, indicate the relationship between the degree of countries' development and the environmental protection. Therefore, the authors 
suggest the countries with high EPI scores as green destinations and the potential sources of green suppliers, which are the basis of green supply chain development.

\section{Literature review}

Sustainable supply chain management could be defined as: "the achievement of social, environmental and economic goals through the integration and coordination of companies and business processes between them" (Varsei et al., 2014). Seuring and Muller (2008) indicate that sustainable supply chain management include managing all flows (material/goods, information and financial) according to all dimensions of sustainable development (economic, environmental and social). Multidimensional performances have to be used for the assessment of sustainable development of each company, not just economic performances (Geng et al., 2017; Ramudhin et al., 2010).

Focusing on sustainability depends on the supply chain leader. Other partners of supply chain, upstream and downstream, in relation to focal company (leader) will respect the rules defined by leader (Varsei et al., 2014). According to research of Aberdeen Group, which included 300 companies around the world, 50\% of the surveyed companies, planned to redesign their supply chain in terms of sustainability (Ramudhin et al., 2010).

The supply chain focused on environmental protection (Tseng et al., 2019), besides economic goals, is known as a green supply chain. The green approach is some kind of a proactive management of environmental issues, with the following aims (Christopher et al., 2007):

- Identifying all interactions among partners that could have a negative impact on the environment;

- Identifying all types of environmental impact as a result of interaction among partners;

- Identifying alternative for the control and prevention of environmental pollution.

According to Srivastava (2007) for the last two decades, there were published 1,500 articles about green supply chain management. But, while the interest for green supply chain is increasing in the sphere of theory, in practice, companies become interested in this area only after the government pressure. Such passive and reactive actions of companies have been showed in a few studies (Holt \& Ghobadian, 2009; Zhu et al., 2007). A negative impact on the environment could be very expensive. Starting from the penalties formulated by national governments and international organizations, through the losing opportunities to achieve the benefits in the case of environmental protection, to damaging the company's image. 
The first phase of supply chain development is the supplier selection process. The supplier selection is a strategic decision of the supply chain managers, and from this decision depends the development of the relationship among partners in the future and the need for the supply chain reengineering. The supplier selection process depends on various factors, such as: the characteristics of raw materials, characteristics of final goods, specificities of market requirements and competitors etc. Also, the choice of supplier depends on the decision if the supply chain will have single or multiple sourcing. Each way of supplying (single or multiple) has its advantages and disadvantages. Regardless of the single or multiple sourcing, the problems of the global supply chain come from the differences between supplying from global and domestic markets. These problems are the result of longer distances, different rules and regulations between the countries, currency fluctuations, customs requirements, and cultural differences (Christopher et al., 2007). However, the interest for global supplying comes from its benefits, such as: low cost of labor, low cost of raw materials, low land and facility costs, low taxes, quality, uniqueness, technical supremacy, penetration to the growth markets, flexibility, access to process and product technology, better product characteristics or better management of capital resources.

Regardless of the choice of the way of supplying and the size of the supplier base, the process of the supplier selection is based on multi-criteria (qualitative and quantitative) (Toloo, 2014). Traditional supply chains in the supplier selection process use general criteria as: the quality of raw materials, available production capacities, lead time, liquidity, reliability, accuracy etc. For the green supply chain, it is very important to question the fulfillment of the environmental protection criteria. So, the green supply chain in the supplier selection process uses general as well as environmental criteria, and that is why the selection process is more complex (Banaeian et al., 2015; Kuo et al., 2015). The supplier selection, according to the environmental criteria, is present in the sustainable supply chains (Konys, 2019; Lo et al., 2018). Those supply chains have an interest for economic development, but only through improving the quality of life of an individual and the whole society. Those supply chains have ability to satisfy the requirements of three bottom lines: economic, environmental and social. In addition, sustainable supply chains could be profitable, but they have to be socially and environmentally responsible.

Defining criteria for the supplier selection process is very important for the decisions to be following (Konys, 2019; Banaeian et al., 2015). For example, in food industry, the quality and safety of food and packing is very important. According to this, the process of supplier selection includes the assessment of the supplier in terms of implementing HACCP, ISO 9000 standards, and also other requirements. Food industry represents the source of greenhouse gas emission and according to that, it could have a great influence on the environment (Grunert, Hieke, \& Wills, 2014). This is one of the reasons why green food became a very 
important issue, for green and sustainability supply chains in food industry. For that purpose, it is necessary to choose the green suppliers (Banaeian et al., 2015).

The main drivers of the implementation of green approach in the supply chain are legislation and green-oriented consumers. In period from 1970 to 1985 , legislation was the basic driver towards greening the companies and this factor is still very important (Frota Neto et al., 2008). In addition, today it could be found a lot of initiatives for minimizing the environmental problems. Some of them are developed in the field of transport, as the most important logistics activity with huge and serious implications on the environment. For example, developing of Trans-European Network (TENs) has a purpose to promote environmental sustainability and energy efficiency through defining green transport corridors. In addition, Marco Polo program is focused on encouraging the transfer of freight transport from road to rail, sea or inland waterways (Aditjandra et al., 2012). NAIADES program supports freight transport by waterway (Islam et al., 2013). In the last years, European Union (EU) defined and implemented a several policies that are very important for greening.

Ecologically aware consumers will choose products with Flower, which is promoted by EU as a certification for green products. By this Flower, EU wants to encourage purchasing of green products. Ecologically aware consumers, in developed countries, usually boycott products that are harmful to the environment. The study from 1989, showed that even then existed ecologically aware consumers in the USA. According to that study, more than half of consumers in America refused to buy products harmful to the environment (Frota Neto et al., 2008). Standard ISO 26000 is developed as an answer to social responsibilities promoted by nongovernmental organizations, industry associations, groups of consumers, media and governments. The primary aim of ISO 26000 is to help companies and business networks to focus on the social responsibility.

In addition, EICC Code of Conduct that was developed by global companies for electronic industry could be used for the assessment of the supply chain responsibility and greening. EICC Code of Conduct shows the level of corporate responsibility in five elements: labor, health and safety, ethics, environment, and management systems (Krueger, 2008). For example, in 2012 HP used EICC Code of Conduct for the purpose of the revision of the supplier base, and decided to develop long-term relationships only with the suppliers operating according to EICC Code of Conduct (Kuo et al., 2015). The companies such as Dell, IBM, Intel, and Sony in the process of supplier selection use the environmental criteria that are defined by EICC Code of Conduct (Kuo et al., 2015). Table 1 shows the list of those criteria. 
Table 1. Environmental criteria for the process of supplier selection according to EICC Code of Conduct

\begin{tabular}{|c|c|c|}
\hline Dimension & Criteria & Explanation \\
\hline \multirow{6}{*}{ 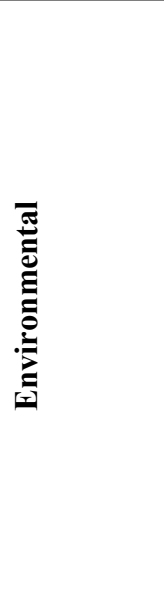 } & $\begin{array}{l}\text { Environmental Permits } \\
\text { and Reporting }\end{array}$ & $\begin{array}{l}\text { All environmental permits need to be obtained, as } \\
\text { well as all reports about the environmental } \\
\text { protection need to be prepared }\end{array}$ \\
\hline & $\begin{array}{l}\text { Pollution Prevention } \\
\text { and Resource } \\
\text { Reduction }\end{array}$ & $\begin{array}{l}\text { All types of waste need to be reduced or } \\
\text { eliminated through modifying production process, } \\
\text { recycling, machines and equipment maintenance }\end{array}$ \\
\hline & Hazardous Substances & $\begin{array}{l}\text { All hazard substances, if released to the } \\
\text { environment, have to be identified and managed, so } \\
\text { as not to endanger the balance of the environment }\end{array}$ \\
\hline & $\begin{array}{l}\text { Wastewater and Solid } \\
\text { Waste }\end{array}$ & $\begin{array}{l}\text { Each wastewater and solid waste have to be } \\
\text { identified, monitored and managed }\end{array}$ \\
\hline & Air Emissions & $\begin{array}{l}\text { Emissions of dangerous materials into the air } \\
\text { have to be characterized, monitored and managed } \\
\text { before and after the discharge. }\end{array}$ \\
\hline & $\begin{array}{l}\text { Product Content } \\
\text { Restrictions }\end{array}$ & $\begin{array}{l}\text { Participants operate according to all applicable } \\
\text { laws, regulations and customer requirements }\end{array}$ \\
\hline
\end{tabular}

Source: Kuo et al., 2015.

The supplier selection process, according to the green approach, includesthe selection of those suppliers that fulfill environmental regulations or standards. Govindan and associates (2013) recognize the traditional and environmental criteria in the process of supplier selection. Top ten criteria for the green supplier selection are Environmental management systems, Quality, Price/cost, Service, Technology, Green design, Green image, Environmental performance, Environmental competences, and Green collaboration with suppliers (Govindan et al., 2013; Kuo et al., 2015). Some companies have requirements in terms of ISO 14001 implementation, because this standard became a measure for the assessment of level of greening of suppliers. Authors Ho, Xu and Dey through analyzing the research papers found that in $87.18 \%$ of cases used traditional or general criteria in the process of supplier selection, such as lead time, price, manufacturing capability, service, technology, research and development, finance, flexibility, reputation, and environment, and the most important criterion was quality (Koromyslova \& Visser, 2015). Some authors note that in process of selecting green suppliers, quality is the most common criterion (Govindan et al., 2013; Kuo et al., 2015).

The greening process of supply chain, through the implementation of the green approach in the supplier selection process, does not come into question (Hou \& Xie, 2019; Lo et al., 2018). The problem is in the velocity of the implementation of this approach. The following research will show which countries are highly ranked, in terms of implementing the green approach, based on the assumption that those countries are the potential destination for green-oriented suppliers. 


\section{Research methodology}

In the last few years, recently, there has been a consensus that the environmental issue has followed by industrial development (Mariano et al., 2017; Khan et al., 2017; Kuo et al., 2015). Therefore, it is expected that more developed countries have more opportunities for applying green approaches in any business area (Liu et al., 2018; Khan et al., 2017). In order to verify this assumption in the following research, the authors usd the GDP and Logistic Performance Index, as indicators of country development, and Environmental Performance Index, as an indicator of the implementation of the green approach. In addition, the authors point out that a high EPI can be perceived as the source for green-oriented companies and green suppliers for global supply chains.

Logistics Performance Index (LPI) has been calculated since 2007, through the online survey, where a great number of logistic professionals participate (more than $1,000)$ from 130 countries around the world. This index could be an indicator of development of each country and it evaluates (Ilsuk\& Hokey, 2011):

- Efficiency of customs process (customs);

- Quality of transport infrastructure (infrastructure);

- Ease of arranging competitively priced shipments (international shipments);

- Competence and quality of logistics services (logistics quality and competence);

- Ability to track and trace consignment (tracking and tracing); and

- Frequency of shipments that reach the consignees at the right time (timeliness).

Environmental Performance Index (EPI) was introduced for the first time in 1999, but under another name, as Environmental Sustainability Index (ESI). It has been recognized as EPI since 2006, every other year. EPI is used as a measure for "ecosystem vitality" and "environmental health". EPI is a result of 25 indicators of environmental performances of different countries. For measuring "the ecosystem vitality", the indicators were grouped into following categories: air pollution effects on ecosystems, water effects on ecosystems, biodiversity and habitat, productive natural resources and climate change, while "the environmental health" was the result of indicators that were grouped into: environmental burden of disease, air pollution and water (Ilsuk\& Hokey, 2011; Gallego-Álvarez et al., 2014). The idea for connecting these two indexes, in order to select green destinations as a base of green suppliers, came from the research by Verfaillie and Bidwell (2000). They showed an index for measuring eco-efficiency, as a symbiosis of business and environmental performance. The mathematical expression of eco-efficiency is:

$$
\text { Eco-efficiency }=\frac{\text { Product or service value }}{\text { Environmental influence }}
$$


According to the previous mathematical expression, Ilsuk\& Hokey (2011) showed the GLPI as a measure of logistics performance and environment performance, at the country level (Ilsuk\& Hokey, 2011), and authors did not analyze all the elements of LPI and EPI, but exclusively those elements that had a great impact on the environment, which were Infrastructure and Timeliness.:

$$
\text { GLPI }=\frac{\text { Logistics performance }}{\text { Envrionmental impact }} \quad \text { or } \quad \text { GLPI }=\frac{\text { LPI }}{\text { EPI }}
$$

According to this research, the authors of the paper examined the correlation between the degree of development of countries (measured by GDP per capita) and LPI and EPI. Using data about LPI and EPI from2018 and GDP per capita (2018) the authors of the paper selected random sample of 56 countries. Table 2 shows the selected countries with theirs GDP per capita and LPI and EPI in 2018. In order to answer the research questions, the authors defined the following hypotheses:

- H1: There is a high degree of correlation between GDP per capita and LPI and EPI;

- H2: Between economic wealth of a country and ecological performance, there is an important positive relation.

The defined hypotheses are based on the fact that the high LPI is present in the countries with a developed infrastructure, which accelerates and facilitates the carrying out of the logistics activities. It is also expected that the countries that countries with high LPI have a high GDP, which is a condition for higher allocations and investments in logistics infrastructure. In this regard, the first hypothesis was formulated in order to examine the assumption that the developed logistics infrastructure created the potential for environmental protection. In order to examine the second hypothesis, the authors analyze the ratio between GDP per capita and EPI. In the next chapter, in the order to prove the formulated hypotheses, the authors used SPSS software package. In addition, in order to testthe hypotheses, the authors used a correlation analysis, cluster analysis, and variance analysis. 
Table 2. GDP per capita, LPI and EPI in 2018. (for random selected countries)

\begin{tabular}{|c|c|c|c|c|c|c|c|c|c|c|c|}
\hline Country & GDP (\$) & LPI & EPI & Country & GDP (\$) & LPI & EPI & Country & GDP (\$) & LPI & EPI \\
\hline Argentina & 11633.50 & 2.89 & 59.30 & $\begin{array}{l}\text { United } \\
\text { Kingdom }\end{array}$ & 43043.23 & 3.99 & 79.89 & Panama & 15592.57 & 3.28 & 62.71 \\
\hline Australia & 57354.96 & 3.75 & 74.12 & Ghana & 2202.31 & 2.57 & 49.66 & Peru & 6941.24 & 2.69 & 61.92 \\
\hline Belgium & 47583.07 & 4.04 & 77.38 & Guatemala & 4472.89 & 2.41 & 52.33 & Poland & 15468.48 & 3.54 & 64.11 \\
\hline Bulgaria & 9427.73 & 3.03 & 67.85 & India & 2005.86 & 3.18 & 30.57 & Russia & 11370.81 & 2.76 & 63.79 \\
\hline $\begin{array}{l}\text { Bosnia and } \\
\text { Herzegovina }\end{array}$ & 6072.18 & 2.81 & 41.84 & Israel & 41719.73 & 3.31 & 75.01 & $\begin{array}{l}\text { Saudi } \\
\text { Arabia }\end{array}$ & 23338.96 & 3.01 & 57.47 \\
\hline Brazil & 9001.23 & 2.99 & 60.70 & Japan & 39159.42 & 4.03 & 74.69 & Serbia & 7252.40 & 2.84 & 57.49 \\
\hline Bolivia & 3548.59 & 2.36 & 55.98 & Jordan & 4312.18 & 2.69 & 62.20 & Singapore & 66188.78 & 4.00 & 64.23 \\
\hline Cambodia & 1512.13 & 2.58 & 43.23 & Kuwait & 33994.38 & 2.86 & 62.28 & Slovenia & 26115.91 & 3.31 & 67.57 \\
\hline Canada & 46303.91 & 3.73 & 72.18 & Liberia & 677.32 & 2.23 & 41.62 & South Africa & 6372.61 & 3.38 & 44.73 \\
\hline China & 9976.68 & 3.61 & 50.74 & Luxembourg & 116654.26 & 3.63 & 79.12 & Sweden & 54589.06 & 4.05 & 80.51 \\
\hline Cote d'Ivoire & 2314.05 & 3.08 & 45.25 & Morocco & 3222.20 & 2.54 & 63.47 & Taiwan & N/A & 3.60 & 72.84 \\
\hline Colombia & 6716.91 & 2.94 & & Mexico & 9686.51 & 3.05 & 59.69 & Tunisia & 3438.79 & 2.57 & 62.35 \\
\hline Cuba & 8821.82 & 2.20 & 63.42 & Macedonia & 6088.97 & 2.70 & 61.06 & Turkey & 9455.59 & 3.15 & 52.96 \\
\hline Croatia & 15014.09 & 3.10 & 65.45 & Montenegro & 8846.06 & 2.75 & 61.33 & Ukraine & 3096.82 & 2.83 & 52.87 \\
\hline $\begin{array}{l}\text { Czech } \\
\text { Republic }\end{array}$ & 23415.84 & 3.68 & 67.68 & Malta & 30437.22 & 2.81 & 80.90 & UAE & 43839.36 & 3.96 & 58.90 \\
\hline Germany & 47810.51 & 4.20 & 78.37 & Nigeria & 2027.78 & 2.07 & 54.76 & USA & 62996.47 & 3.89 & 71.19 \\
\hline $\begin{array}{l}\text { Dominican } \\
\text { Republic }\end{array}$ & 8050.63 & 2.66 & 64.71 & Netherlands & 53044.53 & 4.02 & 75.46 & Uruguay & 17277.97 & 2.69 & 64.65 \\
\hline Egypt & 2537.13 & 2.82 & 61.21 & Norway & 81734.47 & 3.70 & 77.49 & Venezuela & N/A & 2.23 & 63.89 \\
\hline Spain & 30389.36 & 3.83 & 78.39 & Pakistan & 1482.31 & 2.42 & 37.50 & & & & \\
\hline
\end{tabular}

Source: Environmental Performance Index, The World Bank (a), The World Bank (b) 


\section{Research results and discussion}

In order to testthe relationship between GDP per capita and LPI and EPI, the authors use the correlation analysis. In this respect, Table 3 shows the correlation between GDP per capita and LPI and EPI in analyzed countries. Based on the results in Table 3, the conclusion is that there is a high degree of correlation between the observed variables, that is, better position of the country, in economic terms, creates the possibility for greater investments in the logistics infrastructure, and in such countries, as a result, a larger LPI is expected. In addition, the analysis of the correlation between GDP per capita and EPI can also indicate a high degree of correlation or a confirmation that economically more developed countries have more opportunities, in terms of investment in environmental protection.

Table 3. Correlations between GDP per capita and LPI and EPI in 2018.

\begin{tabular}{|c|c|c|c|c|c|c|c|}
\hline & & $\begin{array}{c}\text { GDP } \\
\text { per } \\
\text { capita }\end{array}$ & LPI & & & $\begin{array}{c}\text { GDP } \\
\text { per } \\
\text { capita }\end{array}$ & EPI \\
\hline \multirow{3}{*}{$\begin{array}{l}\text { GDP } \\
\text { per } \\
\text { capita }\end{array}$} & $\begin{array}{l}\text { Pearson } \\
\text { Correlation }\end{array}$ & 1 & $.734(*)$ & \multirow{3}{*}{$\begin{array}{l}\text { GDP } \\
\text { per } \\
\text { capita }\end{array}$} & $\begin{array}{l}\text { Pearson } \\
\text { Correlation }\end{array}$ & 1 & $.694(*)$ \\
\hline & $\begin{array}{l}\text { Sig. (2- } \\
\text { tailed) }\end{array}$ & & .000 & & $\begin{array}{l}\text { Sig. (2- } \\
\text { tailed) }\end{array}$ & & .000 \\
\hline & $\mathrm{N}$ & 54 & 54 & & $\mathrm{~N}$ & 54 & 53 \\
\hline \multirow{3}{*}{ LPI } & $\begin{array}{l}\text { Pearson } \\
\text { Correlation }\end{array}$ & $.734(*)$ & 1 & \multirow{3}{*}{ EPI } & $\begin{array}{l}\text { Pearson } \\
\text { Correlation }\end{array}$ & $.694(*)$ & 1 \\
\hline & $\begin{array}{l}\text { Sig. (2- } \\
\text { tailed) }\end{array}$ & .000 & & & $\begin{array}{l}\text { Sig. (2- } \\
\text { tailed) }\end{array}$ & .000 & \\
\hline & $\mathrm{N}$ & 54 & 56 & & $\mathrm{~N}$ & 53 & 55 \\
\hline
\end{tabular}

Developed countries have more possibilities for environmental protection. Wealthy countries have high EPI scores, while poor countries have a very low EPI scores. This is at the same time a confirmation of the hypothesis that more developed and wealthy countries can provide environmental protection. However, countries with sources of renewable energy (hydropower and geothermal energy) could be the source of green-oriented companies, regardless of GDP level.

Table 4. Paired correlations between LPI and EPI

\begin{tabular}{lcccr}
\hline & N & Correlation & \multicolumn{1}{c}{ Sig. } \\
\hline Pair 1 & LPI \& EPI - 2018 & 55 & .563 & .000 \\
\hline Pair 2 & LPI \& EPI - 2016 & 55 & .494 & .000 \\
\hline Pair 3 & LPI \& EPI - 2014 & 54 & .520 & .000 \\
\hline Pair 4 & LPI \& EPI - 2012 & 54 & .523 & .000 \\
\hline Pair 5 & LPI \& EPI - 2010 & 52 & .508 & .000 \\
\hline \multicolumn{2}{c}{ Source: Authors calculation }
\end{tabular}


The authors were testing the correlation between LPI and EPI in the last four reports (period from 2010 to 2018). According to the results from Table 4 there is a great level of correlation between those two variables. In order to test a relationship between LPI and EPI, the authors used regression analyses. The results of testing the relationship between the LPI and EPI for 2018 are showed in Table 5. According to these results, it can be concluded that the level of ecological orientation of the country is determined by logistics performance of that country $(\mathrm{p}<0.05)$. Table 5 also shows that an independent variable (LPI) is statistically predicting well a dependent variable (EPI). In other words, the regression model is well-appointed.

Table 5. Analysis of variance (LPI and EPI)

\begin{tabular}{llcrcrc}
\hline Model & & $\begin{array}{c}\text { Sum of } \\
\text { Squares }\end{array}$ & Df & $\begin{array}{c}\text { Mean } \\
\text { Square }\end{array}$ & F & Sig. \\
\hline 1 & Regression & 2366.713 & 1 & 2366.713 & 24.623 & $.000(\mathrm{a})$ \\
\hline Residual & 5094.242 & 53 & 96.118 & & \\
\hline Total & 7460.955 & 54 & & & \\
\hline
\end{tabular}

a) Predictors: (Constant), LPI 2018

b) Dependent Variable: EPI 2018

Source: Authors calculation

Table 6 shows that the coefficient for 2018 is positive, which means that the regression is not reversed. According to this result, it could be concluded that with the improving of logistics performance, chances for better ecological performance are bigger. Since $\mathrm{p}$ value is less than 0.05 , the conclusion is that the coefficient is statistically significant.

Table 6. Regression analysis (LPI vs. EPI)

\begin{tabular}{|c|c|c|c|c|c|c|c|c|}
\hline \multicolumn{2}{|c|}{ Model } & \multicolumn{2}{|c|}{$\begin{array}{l}\text { Unstandardized } \\
\text { Coefficients }\end{array}$} & \multirow{2}{*}{$\begin{array}{c}\begin{array}{c}\text { Standardi } \\
\text { zed } \\
\text { Coefficient } \\
\text { s }\end{array} \\
\text { Beta }\end{array}$} & \multirow[t]{2}{*}{$\mathbf{T}$} & \multirow[t]{2}{*}{$\begin{array}{c}\text { Sig } \\
\cdot\end{array}$} & \multicolumn{2}{|c|}{$\begin{array}{l}\text { 95\% Confidence } \\
\text { Interval for B }\end{array}$} \\
\hline & & B & $\begin{array}{l}\text { Std. } \\
\text { Error }\end{array}$ & & & & $\begin{array}{l}\text { Lower } \\
\text { Bound }\end{array}$ & $\begin{array}{l}\text { Upper } \\
\text { Bound }\end{array}$ \\
\hline \multirow[t]{2}{*}{1} & (Constant) & 26.987 & 7.254 & & $\begin{array}{r}3.72 \\
0\end{array}$ & $\begin{array}{r}.00 \\
0\end{array}$ & 12.437 & 41.538 \\
\hline & LPI 2018 & 11.311 & 2.280 & .563 & $\begin{array}{r}4.96 \\
2\end{array}$ & $\begin{array}{r}.00 \\
0\end{array}$ & 6.739 & 15.884 \\
\hline
\end{tabular}

a) Dependent Variable: EPI 2018

Source: Authors calculation 
Using the cluster analysis on the group of randomly selected countries, and within the SPSS program, the countries were expected to belong to the second cluster, according to high LPI and EPI results. However, the analysis of the cluster membership for each individual country showed some deviations.

Some countries belong to the second cluster due to high LPI and some to the first, due to low EPI (those countries are China and South Africa) and the second cluster includes many more (Argentina, Bulgaria, Brazil, Cuba, Croatia, Dominican Republic, Egypt, Guatemala, Jordan, Kuwait, Morocco, Mexico, Macedonia, Montenegro, Malta, Peru, Russia, Saudi Arabia, Serbia, Tunisia, Uruguay and Venezuela). These deviations can be easily noticed in Figure 1.

These results are not a surprise, since they were also present in some previous research. According to this, wealthy countries, which are well known as oil producers, could have a low EPI score, with high GDP (Ilsuk \& Hokey, 2011). According to Zhu et al. (2007) China, as a great supplier of numerous global companies, is increasingly considering the issue of Green Supply Chain Management. China has become the basic manufacturing country, but this also means that this country is facing the environmental protection issue. Companies from China recognize the importance of the green approach implementation in all business areas, but until today, they did not achieve any significant results (Christopher et al., 2007). Thus, the mentioned deviations indicate that proven hypotheses can be used as some kind of preliminary criteria in deciding the choice of the country of origin of the partner, bearing in mind the ecological orientation of the supply chain, but not as a key criterion. 
Figure 1. Comparation of LPI and EPI in 2018. (for random selected countries)

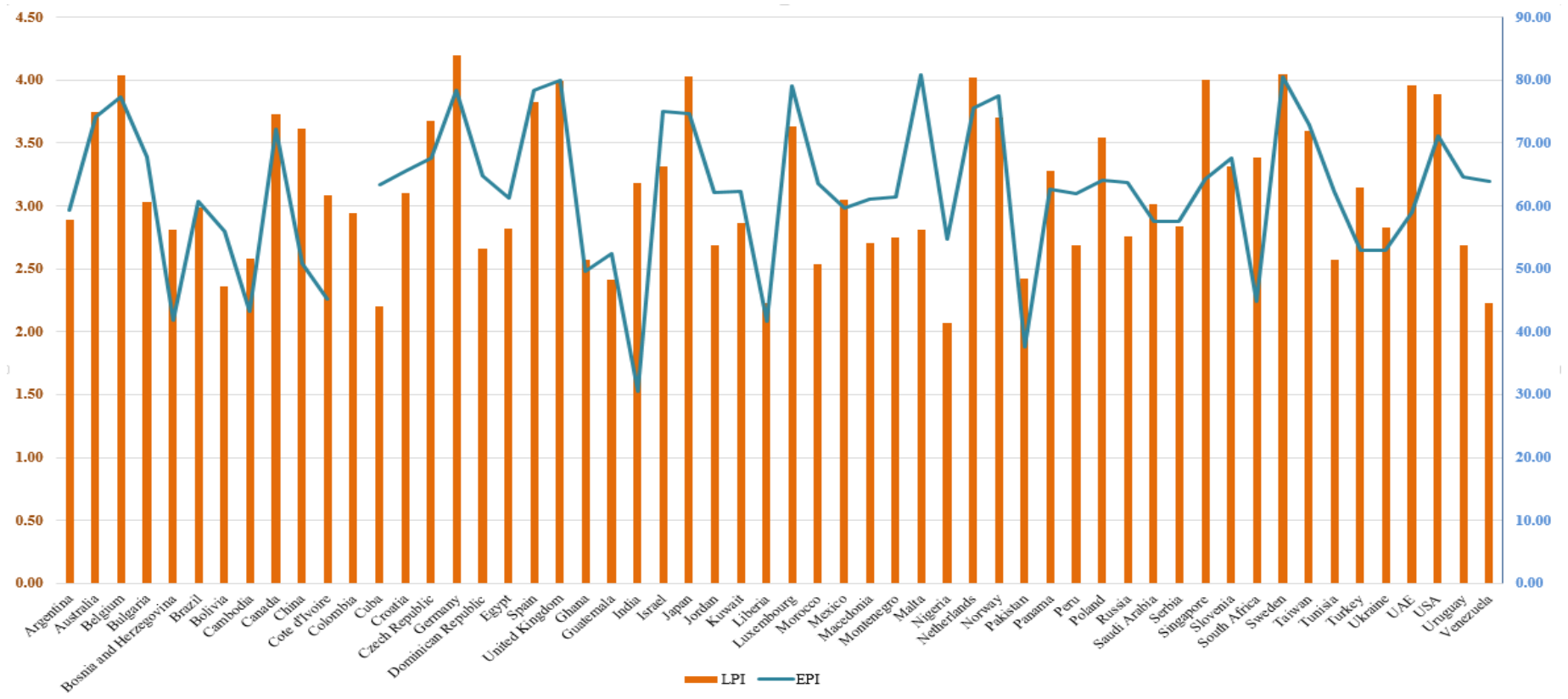

Source: Environmental Performance Index, The World Bank (a), The World Bank (b) 


\section{Conclusions}

Supply chains are global networks of different partners that are included in all processes, from producing raw materials to delivery final goods. Each partner of the supply chain has a primary aim, and that is profitability at the level of the supply chain. This primary aim the partners achieve through: increasing sale, reducing costs, and using all the competitive advantage of a business through the supply chain.

In literature concerning supply chains, green approach is identified as ecofriendly or as a sustainability approach. The problem is that green approach is rarely incorporated in the supply chain performance measure, or in practice, this approach is often neglected as non-value-adding approach. Nevertheless, the connection of lean and green approach in one supply chain strategy could have a positive influence on the environmental protection. For example, the green supply chain is interested in minimizing negative impact on the environment, while the lean supply chain has an aim to reduce all the waste and non-value-adding activities. Thus, minimizing waste, as a part of green supply chain, leads to a better exploitation of natural resources and efficiency, and that is a part of the lean supply chain. Such an interpretation of green supply chain will be a driving force for the implementation of green approach.

Based on the conducted research, it can be concluded that the LPI and EPI indicators can be used as preliminary criteria in designing a green supply chain. They can serve as a starting point in the process of identifying countries as a source of suppliers, or partners who are environmentally oriented. However, these indicators can in no way be used as the only relevant indicators in making the final decision on the choice of the country of origin and partner. Especially in the modern business environment, when in order to ensure a sustainable supply chain, partners want to provide a compromise between economic, sociological and ecological interests.

The authors emphasize that the research results can be used only in preliminary analyses, but they emphasize that greening of supply chains cannot be carried out starting from the downstream supply chain, but from the upstream supply chain or from choosing the suppliers responsible for supplying green raw materials. The research results are signal that the implementation of green orientation can be used as a source of competitive advantage. However, the authors are concerned about the fact that there has been a serious decline in the environmental performance by countries between two consecutive EPI publication periods (2016-2018). Therefore, there is a need to find the reasons for that, despite the fact that the application of green orientation in the business is becoming increasingly important. 


\section{References}

Aditjandra, P. T., Zunder, T. H., Islam, D. M. Z. \& Vanaale, E. (2012). Investigating freight corridors towards low carbon economy: evidence from the UK. Procedia: Social and Behavioral Sciences, 48, 1865-1876. doi: 10.1016/j.sbspro.2012.06.1161

Banaeian, N., Mobli, H., Nielsen, I. E. \& Omid, M. (2015). Criteria definition and approaches in green supplier selection - a case study for raw material and packaging of food industry. Production \& Manufacturing Research, 3 (1), 149-168. DOI: 10.1080/21693277.2015.1016632

Christopher, M., Jia, F., Khan, O., Mena, C., Palmer, A. \& Sandberg, E. (2007). Global Sourcing and Logistics. Centre for Logistics and Supply Chain Management at Cranfield School of Management on behalf of the Department for Transport (DfT) under Logistics Policy project number - LP 0507.

Environmental Performance Index, epi2018policymakerssummaryv01.pdf (yale.edu),Accessed $4^{\text {th }}$ June 2021.

Frota Neto, J. Q., Bloemhof-Ruwaard, J. M., van Nunen, J. A. E. E. \&van Heck, E. (2008). Designing and Evaluating Sustainable Logistics Networks. International Journal of Production Economics, 111 (2), 195-208. doi.org/10.1016/j.ijpe.2006.10.014

Gallego-Álvarez, I., Vicente-Galindo, P., Galindo-Villardón, P. \& Rodríguez-Rosa, M. (2014). Environmental Performance in Countries Worldwide: Determinant Factors and Multivariate Analysis. Sustainability, 6 (11), 7807-7832. doi:10.3390/su6117807

Geng, R., Mansouri, S. A. \& Aktas, E. (2017). The relationship between green supply chain management and performance: a meta-analysis of empirical evidences in Asian emerging economies. International Journal of Production Economics, 183 (A), 245258.

Govindan, K., Rajendran, S., Sarkis, J. \& Murugesan, P. (2013). Multi criteria decision making approaches for green supplier evaluation and selection: A literature review. Journal of Cleaner Production, 98 (July), 66-83.

Grunert, K. G., Hieke, S. \& Wills, J. (2014). Sustainability labels on food products: Consumer motivation, understanding and use. Food Policy, 44 (February), 177-189. doi: 10.1016/j.foodpol.2013.12.001

Holt, D. \& Ghobadian, A. (2009). An empirical study of green supply chain management practices amongst UK manufacturers. Journal of Manufacturing Technology Management, 20 (7), 933-956.

Hou, Q. \& Xie, L. (2019). Research on Supplier Evaluation in a Green Supply Chain. Discrete Dynamics in Nature and Society, 2-14. https://doi.org/10.1155/2019/2601301

Ilsuk, K. \& Hokey, M. (2011). Measuring supply chain efficiency from a green perspective. Management Research Review, 34 (11), 1169-1189. DOI 10.1108/01409171111178738

Islam, D. Z., Meier, J. F., Aditjandra, T. P. Zunder, H. Th. \& Pace, G. (2013). Logistics and supply chain management. Research in Transportation Economics, 41 (1), 3-16.

Khan, S. A. R., Qianli, D., Bo, W. S., Zaman, K. \& Zhang, Y. (2017). Environmental logistics performance indicators affecting per capita income and sectoral growth: evidence from a panel of selected global ranked logistics countries. Environmental Science and Pollution Research, 24 (2), 1518-1531.

Kim, M. G., Woo, C., Rho, J. J., \& Chung, Y. (2016). Environmental Capabilities of Suppliers for Green Supply Chain Management in Construction Projects: A Case Study in Korea. Sustainability, 8 (1), 82-99. 
Konys, A. (2019). Green Supplier Selection Criteria: From a Literature Review to a Comprehensive Knowledge Base. Sustainability, 11 (15), 2-41.

Koromyslova, E. \& Visser, J. (2015). A Statistical-Based Framework for Predicting Supplier's Behavior to Quality Requirement Changes in Supply Chain. iBusiness, 7, 137-142.

Krueger, D. A. (2008). The ethics of global supply chains in China-Convergences of east and west. Journal of Business Ethics 79 (1-2), 113-120.

Kuo, T. Ch., Hsu, Ch. W. \& Li, J. Y. (2015). Developing a Green Supplier Selection Model by Using the DANP with VIKOR. Sustainability, 7 (2), 1661-1689. doi:10.3390/su7021661

Liu, J., Yuan, C., Hafeez, M. \& Yuan, Q. (2018). The relationship between environment and logistics performance: evidence from Asian countries. Journal of Cleaner Production, 204, 282-291.

Lo, H. W., Liou, J. J. H., Wang, H. Sh. \& Tsai, Y. S. (2018). An integrated model for solving problems in green supplier selection and order allocation. Journal of Cleaner Production, 190, 339-352.

Mariano, E. B., Gobbo, J. A. Jr., de Castro Camioto, F. \& do Nascimento Rebelatto, D. A. (2017). CO2 emissions and logistics performance: a composite index proposal. Journal of Cleaner Production, 163, 166-178.

Ramudhin, A., Chaabane, A. \& Paquet, M. (2010). Carbon market sensitive sustainable supply chain network design. International Journal of Management Science and Engineering Management, 5 (1), 30-38.

Seuring, S. \& Muller, M. (2008). From a literature review to a conceptual framework for sustainable supply chain management. Journal of Cleaner Production, 16 (15), 16991710. doi: 10.1016/j.jclepro.2008.04.020

Srivastava, S. K. (2007). Green supply-chain management: A state-of-the-art literature review. International Journal of Management Reviews, 9 (1), 53-80. doi: 10.1111/j.14682370.2007.00202.x

The World Bank (a), GDP per capita (current US\$) | Data (worldbank.org), Accessed $4^{\text {th }}$ June 2021.

The World Bank (b), Global Rankings 2018 | Logistics Performance Index (worldbank.org), Accessed $4^{\text {th }}$ June 2021.

Toloo, M. (2014). Selecting and full ranking suppliers with imprecise data: A new DEA method. The International Journal of Advanced Manufacturing Technology, 74 (5-8), 11411148.

Tseng, M. L., Islam S. M., Karia, N., Fauzi, F. A. \& Afrind, S. (2019). A literature review on green supply chain management: Trends and future challenges. Resources, Conservation and Recycling, 141, 145-162.

Varsei, M., Soosay, C., Fahimnia, B. \& Sarkis, J. (2014). Framing sustainability performance of supply chains with multidimensional indicators. Supply Chain Management: An International Journal, 19 (3), 242-257.

Verfaillie, H. \& Bidwell, R. (2000). Measuring Eco-efficiency - A Guide to Reporting Company Performance. World Business Council for Sustainable Development: Geneva.

Viswanadham, N. \& Samvedi, A. (2013). Supplier selection based on supply chain ecosystem, performance and risk criteria. International Journal of Production Research, 51 (21), 6484-6498. DOI: 10.1080/00207543.2013.825056

Zhu, Q., Sarkis, J. \& Lai, K. (2007). Green supply chain management: pressures, practices and performance within the Chinese automobile industry. Journal of Cleaner Production, 15 (11-12), 1041-1052. 


\section{PROCES SLEKCIJE DOBAVLJAČA ZASNOVAN NA GREEN PRISTUPU}

Apstrakt: Fokus na profitu i kontinuirana borba za većim tržišnim učešćem postepeno su doveli do zanemarivanja životne sredine. Oportunističko ponašanje kompanija, narušavanjem ekološkog okruženja dovelo je indirektno do zanemarivanja i samih potrošača. U tom smislu, u poslednje vreme je sve prisutnija implementacija green pristupa u sve segmente poslovanja. Kada je reč o lancu snabdevanja i o njegovoj održivosti u ekološkom smislu, pitanje adekvatne selekcije dobavljača i/ili partnera je prioritet. Proces selekcije dobavljača je prva faza u procesu dizajniranja lanca snabdevanja. Prema tome, od nje jako puno zavisi da li će i čitav lanac snabdevanja biti green orijentisan. Cilj rada je da ukaže na sve prisutniju primenu green pristupa u lancu snabdevanja, a pre svega u procesu selekcije dobavljača. Osim toga, u radu se analizira uticaj ekonomskog okruženja, u smislu većeg stepena razvijenosti, na implementaciju green pristupa. U cilju ispitivanja hipoteze autori analiziraju indekse EPI i LPI, kao i korelaciju između njih, i na temelju analize ovih indeksa upućuju na zemlje sa većim stepenom implementacije green pristupa, koje mogu biti značajan izvor green partnera, odnosno green dobavljača.

Ključne reči: green pristup, lanac snabdevanja, dobavljači, okruženje, EPI, LPI

\section{Authors' biographies}

Aleksandra Anđelković is an Associate Professor at the Faculty of Economics, University of Nis, for narrow scientific field of business management, for the group of courses Strategic Logistics Management, International Logistics and Marketing Channels. In 2015, she defended the doctoral dissertation entitled Supply chain risk management for the purpose of increasing its resilience. Until now she was two times a scholar and researcher of the Austrian Agency for International Cooperation in Education and Research, at the University of Vienna (2013), and Vienna University of Economics and Business (2016). Her key interest areas are: strategic management of logistics, international logistics, supply chains, international marketing, and marketing channels. So far, she has published more than 60 papers in journals and proceedings from the conferences (national and international).

Goran Milovanović is presently employed as full professor at the Faculty of Economics, University of Niš. He defended PhD dissertation in 1997 at the Faculty of Economics, University of Belgrade. He has participated in three projects conducted by the Ministry of Science and Environment Protection Republic of Serbia and two international projects. He actively participated in two study stays abroad. He is a member in the Scientific Association of Economists of Serbia and Serbian Marketing Association. He published as coauthor or independently eight books and more than 200 articles, both, in scientific journals and scientific conferencess of national or international character. 